\title{
Light, Dark, and Grey: Representation of Hero in William Morris's The Story of Sigurd the Volsung and the Fall of the Niblungs
}

\section{Minjie Su ${ }^{1}$}

Published online: 24 September 2018

(C) The Author(s) 2018

\begin{abstract}
Acclaimed and influential, the pre-Raphaelite artist and author William Morris's long narrative poem The Story of Sigurd and the Fall of the Niblungs (1876) fits, at first sight, the Victorian interpretation of the Old Norse world. It is essentially a world deprived of the original context, where the heroes were re-moulded within the contemporary frame. However, as the story goes, Sigurd's life gradually drifts away from that of a Victorian conventional hero: unlike other Old-Norse-made-Victorian heroes preceding him, he fell prey to the power of the dark-the Niblungs or 'the Cloudy people'. In this case, is he still a hero? If yes, what sort of hero will he be? It is the goal of this paper to address these questions. They will be approached through three successive steps: the first part will introduce the image of the Victorian Old Norse heroes in general as representations of light in contrast to absolute darkness, represented by the two Baldur-themed narrative poems from the 1860s. In the second, Sigurd's rise and fall as a conventional Victorian hero will be examined through analysing a series of key events in his life. At last, it will be argued that, instead of being a symbol of perfect light, Sigurd is essentially a hero of the grey-a compromise between the idealised and the real, which accords with Morris's own life experience and perception of heroism.
\end{abstract}

Keywords William Morris · Völsunga saga Old Norse literature · Victorian literature $\cdot$ Sigurd the Volsung $\cdot$ Post-medieval reception

Minjie Su

minjie.su@linacre.ox.ac.uk

1 Linacre College, University of Oxford, St Cross Road, Oxford, UK 
The Victorian era saw an increased popularity of the mythological tales from the ancient North (Ashurst 2009, pp. 45-71). ${ }^{1}$ But the Victorian North was essentially a North deprived of its original context: no longer recognizing the underlying social norms in Old Norse literature, Victorian authors took the liberty to expand and embellish their subject matter based on the world they were living in rather than the world in which these tales were told and written down. The tales, as a result, became a representation and reflection of Victorian values, and the world that emerged from this approach was a world interpreted, according to David Ashurst, 'in terms of absolute good and evil' and 'as responses to the binary oppositions [...] of light and darkness' (Ashurst 2009, pp. 47, 49). It comes as no surprise that this tradition of dualism offered a new cosmos within which the Victorian writers, as their confidence in the subject matter increased, could freely re-mould their heroes of choice into representations of light, who, in Thomas Carlyle's words, 'enlightened the darkness of the world' (Carlyle 1883, p. 1). ${ }^{2}$

One such hero is Sigurðr, the protagonist of Volsunga saga-a fornaldarsaga (legendary saga) dated to the late thirteenth century-and whose deeds are also recorded in the heroic poems in the Codex Regius, written down in the 1270s. ${ }^{3}$ The story of Sigurðr, anglicised as Sigurd, occupies the bulk of William Morris's narrative epic poem The Story of Sigurd the Volsung and the Fall of the Niblungs. In Morris's rendering, Sigurd bears many traits of this new image of luminous hero of light - as will be explicated below. Many signs indicate that he is expected from birth to embark on a heroic and glorious path, a destiny he quickly fulfils by slaying Fáfnir, the symbol of darkness. After the climactic dragon-slaying episode, however, Sigurd gradually drifts away from the path of a conventional hero through his association with the Niblungs, who little by little taint Sigurd's purity, which eventually leads to his death. By the end of Book III, Sigurd has fallen prey to the dark-can he still be counted as a hero? If yes, what sort of hero would he be? It is the aim of this paper to address these questions and to propose a new type of heroism for Sigurd. To do this, a series of key events in Sigurd's life will be analysed to examine his rise and fall as a hero of light. Then, by introducing the concept of colour to the Victorians' dichotomous interpretation of Old Norse literature, I propose that, instead of being created a symbol of perfect light—represented by the colour of white, Sigurd is essentially a hero of the grey-that is to say, the colour in between. Morris's

\footnotetext{
1 Ashurst gives a concise overview in the opening paragraphs of the Old Norse texts available in English before and in the beginning of Queen Victoria's reign, then he goes on to examine how the Victorian writers interpreted Eddic myths based on the four pillars of the Victorian value system, namely mercantile expansion, technical innovation, military vigour, and belief in God, so the readers could relate themselves to the ancient tales prior to William Morris. For a more detailed account of the development of the reception and adaption of Old Norse material, see Wawn (2002, pp. 3-33).

2 Carlyle sees in the Old Norse myths a constant struggle between light-represented by the gods-and the dark, the chaotic, and the wintry, represented by the Jötuns.

3 Old Norse spelling is used when referred to characters in the Old Norse-Icelandic sources, such as Sigurðr and Baldr. Anglicised forms are used when referred to characters in the Victorian sources. For the composition date of Volsunga saga and its textual relation to other sources, see Aðalheiður Guðmundsdóttir (2012, pp. 68-71). For the structure and content of the Sigurðr story in the Codex Regius, see Haimerl (2012, pp. 32-34) where Haimerl details the basic structure of and summarises the poems.
} 
life and writing career will also be considered in order to demonstrate that Sigurd's development is not random; rather, it accords with the author's own autobiographical experience.

Before plunging into Sigurd's story, however, it is necessary to spare some thought for the Victorian interpretation and representation of Baldr, hailed by Carlyle as 'the sungod' and thought to be the divine prototype of Sigurd, so that we may understand how the image came into being, and what it is like to live and die as such a hero (Carlyle 1883, pp. 9-10).

The Baldr myth is briefly mentioned in Benjamin Thorpe's 1851 volume of Northern Mythology, in which Baldr is placed at the opposite to the blind Höðr, embodiment of darkness, and Baldr's death by his hand interpreted as a temporary loss of light (Thorpe 1851, p. 185). ${ }^{4}$ Based on Thorpe, the story surrounding the god's dream and death (and the prophesied return) was treated extensively in 1860 by Matthew Arnold in the form of a narrative poem titled Balder Dead: An Episode. Although Arnold also mentioned Höðr's blindness and witlessness-characteristics that imply darkness in both sight and mind-it is essentially the flawed world that deprived Balder of the will to live:

For I am long since weary of your storm

Of carnage, and find, Hermod, in your life

Something too much of war and broils, which make

Life one perpetual fight, a bath of blood.

Mine eyes are dizzy with the arrowy hail;

Mine ears are atunn'd with blows, and sick for calm.

Inactive therefore let me lie, in gloom,

Unarm'd, inglorious: I attend the course

Of ages, and my late return to light,

In times less alien to a spirit mild,

In new-recover'd seats, the happier day. (Arnold 1922, vv. 509-19, p. 267)

Arnold's Balder, therefore, is a hero of withdrawal; having become sick of the gods' world and war, he chooses to remain in the realm of the dead over taking a part in the Ragnarök, which, according to Hermod, is fast approaching. Indeed, one may even argue that Balder lets that flawed world end by turning down Hermod's urgent call for help ('I mourn thee, that thou canst not help us then', Arnold 1922, v. 488, p. 266).

If Arnold's Balder only passively challenges the dark world, Robert Buchanan, who picked up the theme in 1866, evidently took it one step further: it is in his Balder the Beautiful: A Song of Divine Death that we find a stark contrast between light and darkness, symbolised by Balder and the world ruled by the old gods,

\footnotetext{
${ }^{4}$ It is noteworthy that, though it is really Loki who orchestrated Baldr's death, the detail is generally overlooked by the Victorian writers. Instead, they showed a much greater preference in creating a Baldr versus Höðr formula, possibly because they are brothers of opposite characteristics. For the interpretation and recreation of the Baldr myth, see also O' Donoghue (2014, pp. 150-169).
} 
respectively. The deity, now recast as a demi-god, ${ }^{5}$ is rejected by the 'black gods' and renounces their belligerent world:

If ever his faint cry

Reach'd to their ears, the dark gods only smiled,

With smiles like sullen lightning on the lips

Of tempest; and he found no comfort there. (Buchanan 1877, p. 132)

Burdened with humans' sufferings ignored by his father Odin, Balder encounters Death alone and sacrifices himself for mankind's sake, thus making himself into a prototype of Christ. ${ }^{6}$ While Arnold's Balder only foresees the coming of a better world, however, Buchanan's Balder witnesses its actual coming: Balder is awakened from the shadow of death by the voice of Christ, repeatedly addressing him as his 'brother' and comparing their ways of life (and death):

The white Christ smiled in Balder's face,

But softly his tears ran-

'Like thee I lived, like thee I loved,

And died, like thee, for Man.' (Buchanan 1877, p. 225)

At last, with death conquered and the hateful gods overthrown, Balder, 'the true light, the one light, the new light' that perished in the old, dark world, now reemerges into Christ's new, bright world (Buchanan 1877, p. 109).

To sum up, the perfect hero we have here is one who, though he may perish temporarily in the darkness, eventually overcomes his enemy and returns with his light unstained. Max Müller, the Oxford-based German philologist, finds in this image of Balder, as portrayed in Arnold and Buchanan, an exemplar of what he conceptualizes as the Solar Hero, whose rise and fall corresponds with the course of the sun and summer. The bright god, in Müller's words, provides a 'divine prototype' for Sigurðr and his German counterpart Siegfried (Müller 1909, pp. 137-38). The influence of Müller's theory is strongly felt in Morris's Sigurd poem, to the point that Amanda Hodgson concludes that 'the whole poem is moulded by the conception of Sigurd as a solar hero' (Hodgson 1987, pp. 114-16). ${ }^{7}$ At least, despite Sigurd's somewhat different ending, a perfect hero of the light is what he has always been aspired to become.

In Morris's rendering, Sigurd's rise to the status of hero is above all confirmed by his slaying of Fafnir. Even before this, however, his glorious destiny is already prefigured by his birth, which itself parallels the sun's journey through night to dawn: Hiordis's labour starts during the night before, then:

\footnotetext{
5 That Baldr is recast as a demi-god, however, is not Buchannan's invention. The belief is also found in Saxo Grammaticus's Gesta Danorum, though here Baldr is rather the villain and Höðr becomes the human hero who triumphs over Baldr and the 'old gods'. Saxo (2008, pp. 69-75).

6 The Christian undertone in Buchanan's poem is discussed in O' Donoghue (2014, pp. 164-67).

7 Hodgson (1987, p. 116) points out the influence of Müller's theory and the Balder image on Morris, and the parallel between Sigurd and the sun, not only in the hero's life course but also in his association with the shining gold. I shall elaborate on this parallel in more detail below.
} 
Through the dark and the dusk she travailed, till at last in the dawning hour Have the deeds of the Volsungs blossomed, and born their latest flower; In the bed there lieth a man-child, and his eyes look straight on the sun, And lo, the hope of the people, and the days of a king are begun. (Morris 1876, vv. $1973-76)^{8}$

Hiordis, though exhausted from childbirth, wastes little time in recounting to the new-born the deeds of his father. When 'the sun rose higher' (v. 1998), she sends the 'golden burden' to King Elf, who at the sight of the boy claims " Lo, how hath the dark tide perished and the dawn of day begun"' (v. 2057). Sigurd is named just before noon-tide, when the sun should be at its highest. Meanwhile, the earls of King Elf are recalling the history of the Volsungs; they finish at sunset, '[a]nd men abide the morrow and the Victory yet to be' (v. 2094).

Having spent his childhood in the Utopian land of King Elf, Sigurd decides to rid the world of Fafnir, who, according to Müller, symbolises the 'dark, cold, wintry, and deathlike' (Müller 1909, p. 138). The whole episode is filled with the image of light struggling against darkness. Sigurd's deed here is also intertwined with the course of the sun and is shown in parallel to his birth-only this time not as a 'manchild', but as a man, a hero. Like his mother, Sigurd's 'labour' also starts the night before:

Great, mighty he was in his working, and the Glittering Heath he clave, And the sword shone blue before him as he dug the pit and the grave: There he hid his hope from the night-tide and lay like one of the dead, And wise and wary he bided; and the heavens hung over his head. (vv. 3440-

The Serpent comes at dawn and re-fills the brightening sky above Sigurd with darkness. This sudden deprivation of light makes the young man recoil a little: 'Himseemed the grave grew straiter, and his hope of life grew chill,/And his heart by the Worm was enfolded, and the bonds of the Ancient Ill' (vv. 3462-63). This is Sigurd's first taste of shadow - of death, but he does not give in. Recalling the glory of the Volsungs, Sigurd smites the Serpent and leaps out of the pit, just in time to catch sight of the rising sun:

Then he leapt from the pit and the grave, and the rushing river of blood, And fulfilled with the joy of the War-God on the face of earth he stood With red sword high uplifted, with wrathful glittering eyes;

And he laughed at the heavens above him for he saw the sun arise, And Sigurd gleamed on the desert, and shone in the new-born light, And the wind in his raiment wavered, and all the world was bright. (vv. 346873)

\footnotetext{
${ }^{8}$ All quotations of the poem are taken from this edition, which can be found via the William Morris Archive website; further reference will be given in text.
} 
It is worth noting that Sigurd shows fear and doubt in this episode. This is Morris's invention; in the Völsunga saga, it is the hero's fearlessness and steadfastness that are stressed, and Fáfnir is no symbol of darkness, only a creature of poison and noise (which is a very practical description) (Finch 1965, p. 31). ${ }^{9}$ The fact that for a fleeting moment Sigurd recoils from the sudden darkness before he could triumph makes more vivid the light versus darkness imagery. It also brings Sigurd closer to Buchannan's Balder: both are overshadowed by darkness but re-emerge later to bring back the light. Moreover, while Buchanan makes explicit the similarity between Balder and Christ, Morris implies the same idea. In Hodgson's brief yet convincing examination of Sigurd's life course, the major events in Sigurd's life are discussed in comparison to those of Christ's. She not only points out the parallel between Morris's wording in describing Sigurd's dragon slaying and the biblical passages depicting Christ's death and resurrection, but also emphasises the similarity between Fafnir and Satan (Hodgson 1987, p. 117). This Christian perspective is further strengthened by the fact that Morris never once refers to Fafnir as a 'dragon' but frequently uses 'Serpent' with a capitalised initial.

Having slain Fafnir, Sigurd has now become the embodiment of light, a bright hero before whom Regin cannot help but shade his eyes (v. 3534). ${ }^{10}$ With this change also comes a transfiguration, a subtle inner change of identity that no ordinary wisdom can perceive. When Regin first sees Sigurd, his immediate reaction is to ask who he might be, as if Sigurd were some random intruder:

Afoot he went o'er the desert, and he came unto Sigurd and stared At the golden gear of the man, and the Wrath yet bloody and bared, And the light locks raised by the wind, and the eyes beginning to smile, And the lovely lips of the Volsung, and the brow that knew no guile;

And he murmured under his breath while his eyes grew white with wrath:

'O who art thou, and wherefore, and why art thou in the path?' (vv. 3537-41)

Regin's puzzling utterance, plus the fact that he only recognises his fosterling after drinking Fafnir's blood (i.e. having gained wisdom), betrays the dazzling nature of Sigurd's newly formed identity: no longer an inexperienced child, he has now become Fafnir's Bane, the name by which he will be known to men. He is now a hero in his own right, with his fame derived from his deeds rather than his lineage. From here, he can set forth on a new phase of life in the outside world. Unsurprisingly, though Morris never specifies the time of this occurrence, in both Gripir's prophecy and the Eagles' urging it is about 'noon-tide' when Sigurd shall slay Regin (v. 3115; v. 3637). Therefore, we may conclude that the dragon-slaying takes place just a while before noon-tide, echoing Sigurd's naming on the day he was born.

\footnotetext{
9 'Hann fnýsti eitri alla leið fyrir sik fram, ok eigi hræddrask Sigurðr né óttask við pann gný' ('He breathed out poison all over the path ahead, but Sigurd was neither frightened nor dismayed by the noise').

${ }^{10}$ Regin the dwarf is Sigurd's foster-father (as it is not at all uncustomary for princes to be fostered by people of lower rank). He is, as he later reveals to Sigurd, a brother to Fafnir, whom he encourages Sigurd to slay.
} 
This point, moreover, also represents the noon-tide of Sigurd's fame and life, when the light he embodies shines the brightest: even the darkness of the Rhine gold temporarily fades away before Sigurd, for, according to the Eagles, his possession of the gold would cleanse the curse and terminate the cycle of blood shedding:

'Bind the red rings, O Sigurd! let the gold shine free and clear!

For what hath the Son of the Volsungs the ancient Curse to fear?'

'Bind the red rings, O Sigurd! for thy tale is well begun,

And the world shall be good and gladdened by the Gold lit up by the sun.' (vv.

3710-14)

Therefore, Sigurd's acquisition of Otter's ransom can be interpreted as a test, ${ }^{11}$ in which the hero's brightness constantly wrestles with the power of the dark. Sigurd's triumph at this point is no less certain than that there can be no night in the light of the midday sun.

That Sigurd himself has become the symbol of light is further stressed by the two following events, in both of which Sigurd transmits the light he himself embodies onto the external world; by doing so, he becomes the Great Man by Carlyle's definition ('the living light-fountain [...] in whose radiance all souls fell that it is well with them', Carlyle 1883, p. 1). The first deed is the wakening of Brynhild, ${ }^{12}$ which bears a striking resemblance to Sigurd's own transfiguration in the dragon-slaying episode. Just as Sigurd rides day and night to the Glittering Heath, his winding journey around Hindfell is also closely tied to the rising and setting of the sun. He enters Brynhild's fort just before dawn, cuts open her all-concealing armour, revealing a body no less shining than his own, and brings her back to life when the sun rises a bit higher-about the same time of Sigurd's own 'return to life' on the Glittering Heath.

Bright burnt the pale blue edges for the sunrise drew anear.

And the rims of the Shield-burg glittered, and the east was exceeding clear:

So the eager edges he setteth to the Dwarf-wrought battle-coat

Where the hammered ring-knit collar constraineth the woman's throat;

But the sharp Wrath biteth and rendeth, and before it fail the rings,

And, lo, the gleam of the linen, and the light of golden things:

Then he driveth the blue steel onward, and through the skirt, and out,

Till nought but the rippling linen is wrapping her about;

Then he deems her breath comes quicker and her breast begins to heave,

So he turns about the War-Flame and rends down either sleeve,

Till her arms lie white in her raiment, and a river of sun-bright hair

\footnotetext{
11 Otter is Regin and Fafnir's shapeshifting brother who is killed by Loki. To compensate, the gods are compelled to pay a large sum of gold as enough to cover the otter skin in which Otter dies. Later this treasure comes to be known as 'Otter's ransom'.

12 As punishment for her disobedience, Odin puts the Valkyrie Brynhild to sleep and decrees that she must marry. She vows, however, only to marry a man who knows no fear. Odin puts her in a fort surrounded by a circle of fire; only he who has the courage to ride through the flame shall awaken and marry Brynhild.
} 
Flows free o'er bosom and shoulder and floods the desert bare. (vv. 3870-81)

This scene, according to Müller, also echoes the Baldr myth: whereas Baldr, light of the spring sun, is killed by a mistletoe branch, Brynhild has been forced into sleep by a 'thorn of winter'; yet unlike Baldur, who returns on his own, Brynhild is more passive and must be revived by Sigurd, as the spring must be wakened by the sun from her 'winter sleep' (Müller 1909, pp. 137-39). The second event is Sigurd's wooing of Brynhild at Lymdale, which shows the same image of sun, light, and summer: Sigurd, dressed in gold, arrives when the sun is uprising, and his visage so bright that he reminds the people of Baldr: "Are the Gods on the earth? did the world change yesternight?/Are the sons of Odin coming, and the days of Baldur the bright?"' (vv. 4444-45) Then, he finds Brynhild again 'in the brightness of the sun' and renews their oaths (v. 4528). Thus far, Sigurd still retains the characteristics of a paragon of light: godlike, guileless in heart, and loved by all. The curse of the gold seems to be eternally overturned, and the future so promising, until the sun slips into the fleecy clouds, and Sigurd travels to the lands of the Niblungs.

Discrepancy begins with the time of Sigurd's arrival. Whereas in the previous episodes Sigurd always travels through the night and arrived at dawn, creating an image of light emerging from darkness, this time he journeys during the day and enters King Giuki's territory at sundown. ${ }^{13}$ By the time when he stands in front of the Niblung fort, the world has already receded from day to dusk:

And into the court of the warriors he came forth after a while,

And looked aloft to the hall-roof, high up and grey as the cloud,

For the sun was wholly perished; and there he crieth aloud. (vv. 4815-17)

The image depicted here is an image of the sun gradually fading into the grey cloud. It foreshadows Sigurd's future mingling with the Niblungs, which, like his confirmation of heroic status, is slowly built up through two key events.

The first is Sigurd's drinking of Grimhild's magical potion. ${ }^{14}$ The scene happens during one evening at the end of summer, when Sigurd has just finished a song of the past deeds of his forefathers. He is approached by Grimhild, proposing a drink for the future, which Sigurd accepts, and the light within him immediately grows dim:

And he drank and smiled on Grimhild above the beaker's rim,

And she looked and laughed at his laughter; and the soul was changed in him.

Men gazed and their hearts sank in them, and they knew not why it was,

Why the fair-lit hall was darkling, nor what had come to pass:

For they saw the sorrow of Sigurd, who had seen but his deeds erewhile,

\footnotetext{
13 King Giuki is the ruler of the Niblungs, father to Gunnar, Hogni, Guttorm, and Gudrun. Giuki's kingdom is described in Volsunga saga as lying 'south of the Rhine' (Finch, p. 44).

14 Giuki's wife Grimhild notices her daughter Gudrun's love for Sigurd and recognises in Sigurd a powerful (and useful) ally to the Niblungs. She induces him to consume a magic potion, so he may forget about Brynhild and take a fancy to Gudrun instead.
} 
And the face of the mighty darkened, who had known but the light of its smile. (vv. 5252-57)

The sequence of events here both echoes and rewrites what happens in King Elf's court after the presentation of the infant Sigurd. Whereas King Elf's men end the feast with the prospective glory of Sigurd as a Volsung, Grimhild envisions a future with Sigurd as a Niblung - by marriage, anyway. Indeed, immediately afterwards, she proclaims Sigurd as a new member of her own house: "Thy father is Giuki the King, and Grimhild thy mother is made,/And thy brethren are Gunnar and Hogni and Guttorm the unafraid."' (vv. 5276-77) Similar words will be uttered again by Sigurd when he weds Gudrun, with an emphasis on their descendants with blood of both the Volsungs and the Niblungs:

'If thou stretch thine hands forth, Giuki, and hail me for thy son:

Then there as thou sitt'st in thy grave-mound when thine earthly day is done,

Thou shalt hear of our children's children, and the crowned kin of kings,

And the peace of the Niblung people in the day of better kings.' (vv. 558689)

The alteration of Sigurd's future is reaffirmed by his subsequent journey, a journey that will undo his past thoroughly. All night he rides, until he stands before Brynhild's fortress, which is now once again encircled by the wildfire that has reappeared due to the potion's memory-erasing effect. But instead of entering the fort in bright daylight as he has once done, he leaves the burg at sunrise:

He hasteneth not nor stayeth; he lets the dark die out

Ere he comes to the burg of Brynhild and rides it round about;

And he lets the sun rise upward ere he rideth thence away. (vv. 5344-46)

Then he wanders during the day without purpose, only to be carried back at dusk to the Niblungs by his horse, who happens to remember the way. Still in shock due to the sudden amnesia, when the 'Cloudy People' at the gate welcome him home 'again', Sigurd accepts and enters the Niblung fort as if it were his place of belonging. Later, to fill the void of his heart, he woos Gudrun.

By overwriting his own past, Sigurd unconsciously deconstructs his previous identity as the personification of light unstained even by the cursed gold. At the very moment he swallows the potion, his visage darkens, which in turn darkens the entire hall, as if its source of light were diminished. This reminds the readers of Sigurd's oaths to Brynhild: 'that the sun should die in the heavens and day come back no more,/Ere I forget thy wisdom and thine heart of inmost love.' (vv. 4645-46) Moreover, to push his point even further, Morris compares the Niblung folk, confused by Sigurd's change, to a group of merry-makers who suddenly fall into silence at the sight of heavy clouds looming in the East, making the afternoon sun 'a hidden wonder' (v. 5304). 
If the potion only initiates the deconstruction of Sigurd's identity and symbolism, then the second event-Sigurd's exchange of form with Gunnar ${ }^{15}$ — completes the process. As soon as the transformation has started, Gunnar and Sigurd fall into a sleep-like trance, in which, as Sigurd observes, Gunnar's visage seems to fade into nothingness:

Long Sigurd gazeth on Gunnar, till he sees, as through a cloud,

The long black locks of the Niblung, and the King's face set and proud:

Then the face is alone on the dark, and the dusky Niblung mail

Is nought but the night before him: then whiles will the visage fail,

And grow again as he gazeth, black hair and gleaming eyes.

And fade again into nothing, as for more of vision he tries. (vv. 5984-89)

One can deduce that this is also how Sigurd appears to Gunnar, since both are in the same condition and linked by eyes and hands. Meanwhile, on the mental level, Sigurd suffers temporary but total amnesia, as if he has to empty his mind and soul and even his already altered identity to embrace a new one-that of Gunnar. We are told, a few stanzas later, that as the transformation approaches its completion, a change comes to Sigurd's heart and he recognises that is 'the soul of Gunnar, and the shaping of his mind' (v. 6014). In other words, in this episode Sigurd literally becomes Gunnar, a Niblung, both in body and soul; the complete loss of his original identity is confirmed by the fact that he could not recognise Brynhild when in Gunnar's guise, though it is made clear later that a simple gaze exchanged between the two is powerful enough to dissolve Grimhild's spell:

For the will of the Norns is accomplished, and outworn is Grimhild's spell,

And nought now shall blind or help him, and the tale shall be to tell:

He hath seen the face of Brynhild, and he knows why she hath come,

And that his is the hand that hath drawn her to the Cloudy People's home:

He knows of the net of the days, and the deeds that the Gods have bid,

And no whit of the sorrow that shall be from his wakened soul is hid. (vv.

6399-6404)

But it is already too late, for the ring of Andvari is returned to Sigurd and the curse is back onto the stage. ${ }^{16}$ Sigurd, the once perfect hero, has committed treachery himself and blended the Light of the Branstock with a darker hue.

As the curtain falls upon Sigurd's life and story, a question arises: since he has fallen prey to the power of the dark, what sort of hero should he be considered to be? To answer it, we must spare a thought for the author himself. After all, no matter the context in which a piece of literature is created, it first of all belongs

\footnotetext{
15 The eldest son of King Giuki, Gunnar at Grimhild's suggestion decides to woo Brynhild. Helped by Grimhild's magic, the brothers-in-law change form with each other and Sigurd rides through the fire in the guise of Gunnar.

16 As part of Otter's Ransom, the ring of Andvari (Andvaranaut, 'Andvari's Gift') is extracted by Loki from the dwarf Andvari. As a result, Andvari puts a curse on whoever takes possession of the ring or the gold. Sigurd gives it to Brynhild as a token of his love and loyalty.
} 
to its creator. Considering that William Morris was also an artist, his portrayal of Sigurd may be able to be explained through an artist's palette.

What we perceive as colour is essentially a trick played upon our visual organs by the visible spectrum of light, which has two extremes: the presence of all light and its absolute absence, which are represented respectively as white and black. If this spectrum is set alongside the dichotomous view of the Victorian Old Norse world, the heroes and villains are easily found at the two ends: heroes, as the sum of all the light in the world, equal to the colour of white, and their dark enemies the colour of black - an image that we have already glimpsed in Balder the Beautiful. In the first half of his life, since Sigurd has successfully constructed his identity as the hero of light, in terms of colours he has every right to be represented as a figure of white, while his enemies would be placed at the opposite end. Therefore, the gradual tarnishing of Sigurd by the Niblungs can be interpreted as a slow blackening of the white, which would produce a hue of grey, the intermediate shade.

To William Morris, grey in fact is an important colour; it is exceedingly rich, and by no means negative or inferior. In Iceland First Seen, a poem composed after Morris's first trip to Iceland in 1871, grey is among the first impressions the poet has for Iceland:

The last of that waste of the mountains

All cloud-wreathed and snow-flecked and grey,

And bright with the dawn that began

Just now at the ending of day.

$[\ldots]$

But that there mid the grey grassy dales

Sore scarred by the ruining streams

Lives the tale of the Northland of old

And the undying glory of dreams? (Morris 1891, pp. 40-41)

This description causes dissatisfaction of his Icelandic friend Jón Sigurðsson, who complains in a letter that Morris considers his motherland 'to be rather grey and scrawny' (Wawn 2002, p. 246). But his dissatisfaction is rather unfair, for grey is by no means negative or trivial to Morris. The colour is frequently found in Morris's other Old Norse and Iceland-related writings. By Wawn's count, it appears four times in Gunnar's Howe above the House at Lithend, while in Morris's travelling journal many shades of grey are used to describe the landscape-dark grey, dreadful grey, lightish grey, yellowish grey, inky grey, just to name a few. Morris's special attention paid to grey may have to do with grey's usefulness as an important background colour in fabric design - this can be seen from Morris's letters to his colour specialist - and a skilful distinction between various shades of grey is also required in pencil sketches (Wawn 2002, pp. 246, 254). Moreover, when Morris delivered a lecture on the early literature of the North some twelve years later after Sigurd, he recalled Iceland with great fondness as 'awful looking [...] yet beautiful to a man with eyes and hearts, and perhaps on the whole the healthiest spot in the world' (Morris 1969, p. 180). If Morris does not value grey, he would not use it so lavishly in describing a country that he regards so highly. 
That Sigurd's lightness is stained and turned into grey, therefore, does not necessarily make him any less of a hero, only a different one. No longer following the path of light versus darkness or white versus black, Morris's Sigurd grows into a hero of the grey, tailored by the author and for the author. Sigurd's greatness lies as much in his great strength as in his resilience; he has, on the one hand, the courage and skill to slay a dragon and win great victories, but on the other he also has what it takes to face failure and mistake. When Brynhild learns Sigurd's betrayal and mourns her fate, Sigurd is the only one who is trying to find a solution. He urges Brynhild to live and to accept the fate they are subjected to: "And I laboured the field of Odin, and e'en this was a joy to my heart,/That we dwelt in one house together, though a stranger's house it were." (vv. 7100-01) When Brynhild refuses to listen, he then suggests that they should get married straight away, come what may: "O live, live, Brynhild beloved! and thee on the earth will I wed,/And put away Gudrun the Niblung — and all those shall be as the dead." (vv. 7119-20) ${ }^{17}$ Sigurd seems to be trying different alternatives here, but the point is to let Brynhild move on and minimise the damage. He still tries to fight back, even though he is now tainted. Unfortunately, Brynhild refuses again and takes death to be the only solution. Compared to Sigurd, she is more of the perfect hero of the light, who cannot suffer herself to become tainted. The Valkyrie does not bend; instead, she breaks.

A glimpse into the poet's life shows that this is the type of heroism that Morris could relate to. For a start, Morris's own course of life seems a parallel to Sigurd's, starting well but taking a tumble in the middle. Born into a wealthy family, Morris as a boy used to dress in armour and ride on the pony that his parents gave him, wandering in the forest near his family's mansion, probably imagining himself as some knight errant (MacCarthy 1994, pp. 9-10). When he was planning the first Iceland trip, however, his financial status had already changed with the income from his family's mining business reduced from $£ 913$ in 1862 to pretty much none in 1871 . Neither has his family life gone smoothly: his wife Jane Morris causes quite a scandal through her relationship with Dante Gabriel Rossetti, one of the founders of the Pre-Raphaelite Brotherhood and Morris's friend. As to make things worse, Rossetti moves into Kelmscott Manor as a joint tenant with the Morris family in 1871. There is little wonder that Morris is generally believed to have embarked upon the Iceland

\footnotetext{
17 Sigurd's persuasions in Morris is an elaborative version of that in Velsunga saga. Although the saga language is more prosaic, that Sigurðr is trying to find solution and to move on is made clear. He first suggests they both accept the situation: 'Ek unna pér betr en mér, pótt ek yrða fyrir peim svikum, ok má pví nú ekki bregða, pví at ávallt er ek gáđa míns geðs, pá harmaði mik pat er pú vart eigi mín kona. En af mér bar ek sem ek mátta, pat, er ek var í konungshọll, ok unða ek pví pó at vér várum ǫll saman' ('I loved you more than myself- though I met with trickery, and now that can't be changed-for when my wits were unclouded it always grieved me that you weren't my wife. But I bore up as best I could, for I was in a royal hall. And yet I was glad that we were all together'). When Brynhild mentions her oath to marry whomever rides over the flame, Sigurd suggests they marry, which, however futile it seems, is apparently an attempt on his part to right the wrong and to fulfill the oath in a more honorable way. Finch (1965, p. 56).
} 
trip at that particular moment, so that Jane and Rossetti may have 'some respite from the inquisitive metropolitan gaze' (Wawn 2002, pp. 246-47). ${ }^{18}$

This experience of falling from the wheel of fortune is also reflected in Morris's change of writing subjects. In the early part of his life, he writes extensively on Arthurian romances and classical epics-it is during this period that he writes the (in)famous Defense of Guinevere and paints La Belle Iseult. In the late 1860s, however, the romantic undertone of his work diminishes, and Morris seems to have stopped believing in the ideal, as if too disappointed in the real world. The representative work of this period, instead, is the three-volume The Earthly Paradise, which starts with a group of Northern sailors undertaking a perilous journey to search for the Promised Land; they only discover at the journey's end that no such paradise exists (Hodgson 1987, pp. 52-53). Old Norse literature, on the other hand, offers a solution to Morris's mid-life crisis. He already includes stories drawn from the Old Norse literary corpus in The Earthly Paradise, so it must come as no surprise that he launches a full Old Norse translation and rewriting project in the following years. As a result, he discovers in Old Norse texts a new type of hero. No longer the idealised Arthurian knight, nor a hopeless wanderer, Morris relocates his admiration in a middle sort-a man who is marred by hardship of life, ends most often in death, but nevertheless keeps on fighting to the very end. Indeed, in his lecture 'The Early Literature of the North-Iceland', Morris specifies that the true religion of the northern people is 'courage' in the face of the hardship of their life in the north, and Iceland-whose people are paragons of the North-becomes to Morris a 'Holy Land' (Morris 1969, p. 190; p. 181). Instead of the glamorous knights, he finds his heroes in the calm Njáll, 'the wise, kindly, and peacemaking neighbour', and Grettir, a man 'carried through good and ill' yet 'stern against fate' (Morris 1969, p. 195; Hodgson 1987, p. 91; MacCarthy 1994, p. 300). ${ }^{19}$ At last, in The Story of Sigurd, we see the summation of all these thoughts.

To conclude, unlike the ever perfect Balder, the life of William Morris's Sigurd is divided into two stages, one of construction and the other of deconstruction: in the "morning" of his life, he gradually rises to be the perfect hero of light, an image that goes hand in hand with the conventional idea of heroism of the day. But as Sigurd steps out of the world of the supernatural and enters the world of men, his purity is contaminated and the spotless white takes on the hue of grey. Likewise, Morris's own life also involves two stages: of dreams and of dreams shattered. Lost in this world, he turns to the other for the courage he needs in his own life, but as a man too experienced to believe in a paradise at that moment, he finds consolation in the realism of the Old Norse sagas, from which he creates for himself a third stage: of dreams not re-gained but compromised. Inevitably, he passes this onto his protagonist and makes him a new hero-a hero of the real,

\footnotetext{
18 Faulkner (1980, p. 63), though reserved on how close Jane and Rossetti really were, admits the difficulty within Morris's marriage and his relationship with Jane.

19 Even when Morris and Magnússon were still working on the translation of Grettis saga, Morris had already found in the outlaw 'a strain he could relate to' and 'a sentiment and a moral sense that somehow made the hopeless looking life of our hero endurable' (MacCarthy 1994, p. 300).
} 
of the imperfect, of the grey. Granted, Morris's Sigurd is no saviour; he cannot change the world about him, he cannot even protect himself against the blackness of his surroundings. Nevertheless, instead of giving up himself totally, he chooses to live through his failure, and to fight on. Even when he falls on that fateful grey dawn, he falls with a clear conscience and candidly entrusts himself to the judgment of the gods:

Nought now is left to repent of, and the tale abides to tell.

I have done many deeds in my life-days, and all these, and my love, they lie

In the hollow hand of Odin till the day of the world go by.

I have done and I may not undo, I have given and I take not again:

Art thou other than I, Allfather, wilt thou gather my glory in vain? (vv. 7330-34)

Acknowledgements An earlier draft of this paper was read at the 5th Annual Háskóli Íslands Student Conference on the Medieval North. I thank Professor Andrew Wawn and Professor Carolyne Larrington for their insightful comments and help, without which this paper would not reach the form as it is. I also thank Chip Robinson for having initially encouraged me to continue working on it and seek publication.

Open Access This article is distributed under the terms of the Creative Commons Attribution 4.0 International License (http://creativecommons.org/licenses/by/4.0/), which permits unrestricted use, distribution, and reproduction in any medium, provided you give appropriate credit to the original author(s) and the source, provide a link to the Creative Commons license, and indicate if changes were made.

\section{References}

Arnold, M. (1922). The poems of Matthew Arnold, 1840-1867. London: Oxford University Press.

Ashurst, D. (2009). Eddic myth, Victorian values: The popularisation of Old Norse mythology in Britain, 1837 to 1876. In K. Schulz \& F. Heesch (Eds.), Aegir: Nordische Mythen um 1900 (pp. 45-71). Heidelberg: Universitätsverlag Winter.

Buchanan, R. W. (1877). Balder the beautiful: A song of divine death. London: W. Mullan \& Son.

Carlyle, T. (1883). On heroes, hero worship, and the heroic in history. London: Chapman and Hall.

Faulkner, P. (1980). Against the age: An introduction to William Morris. London: George Allen \& Unwin.

Finch, R. G. (Trans. and Ed.). (1965). Volsunga saga (The saga of the Volsungs). London: Nelson

Guðmundsdóttir, A. (2012). The origin and development of the Fornaldarsögur as illustrated by Völsunga saga. In A. Lassen, A. Ney, \& Á. Jakobsson (Eds.), The legendary sagas: Origins and development (pp. 59-81). Reykjavík: University of Iceland Press.

Haimerl, E. (2012). Sigurðr, a medieval hero: A manuscript-based interpretation of the 'Young Sigurðr Poems'. In P. Acker \& C. Larrington (Eds.), Revisiting the poetic Edda: Essays on Old Norse heroic legend (pp. 32-52). London: Routledge.

Hodgson, A. (1987). The romances of William Morris. Cambridge: Cambridge University Press.

MacCarthy, F. (1994). William Morris: A life for our time. London: Faber and Faber.

Morris, W. (1876). The Story of Sigurd the Volsung and the Fall of the Niblungs. Stuart Blersch (Ed.). Pre-Kelmscott Edition. William Morris Archive (http://morrisedition.lib.uiowa.edu/). 
Morris, W. (1969). The unpublished lectures of William Morris (E. D. LeMire, Ed.). Detroit: Wayne State University Press.

Müller, F. M. (1909). Comparative mythology; an essay, with additional notes and an introductory preface on solar mythology, by A. S. Palmer. London: G. Routledge and sons. (orig. publ. 1856)

O' Donoghue, H. (2014). English poetry and Old Norse myth: A history. Oxford: Oxford University Press.

Saxo Grammaticus (2008). The histories of the Danes: Books I-IX (H. E. Davidson, Ed. \& P. Fisher, Trans.). Cambridge: D. S. Drewer.

Thorpe, B. (1851). Northern mythology (Vol. 1). London: Lumley.

Wawn, A. (2002). The Vikings and the Victorians: Inventing the old North in nineteenth-century Britain. Cambridge: D.S. Brewer. 